\title{
MILK PRODUCTION OF CROSSBRED HOLSTEIN $\times$ ZEBU ON DIFFERENT PASTURE-MANAGEMENT STRATEGIES
}

\author{
PRODUÇÃO DE LEITE DE VACAS MESTIÇAS HOLANDÊS X ZEBU EM \\ DIFERENTES ESTRATÉGIAS DE MANEJO DE PASTAGENS
}

\section{Danielle Ferreira BAFFA'; Alberto Magno FERNANDES²; Tadeu Silva de OLIVEIRA²; Michele Gabriel CAMILO'; ${ }^{\text {; }}$ Camila da Conceição CORDEIRO'; Sarah Ellen Eduardo BERNARDO ${ }^{3}$}

1. Universidade Estadual do Norte Fluminense Darcy Ribeiro, Programa de Pós-graduação em Ciência Animal, Campos dos Goytacazes, RJ, Brasil; 2. Universidade Estadual do Norte Fluminense Darcy Ribeiro, Programa de Pós-graduação em Ciência Animal, Campos dos Goytacazes, RJ, Brasil; 3. Universidade Estadual do Norte Fluminense Darcy Ribeiro, Programa de Pós-graduação em Ciência Animal, Campos dos Goytacazes, RJ, Brasil

\begin{abstract}
The objective of this study was to evaluate nutrient intake and digestibility, yield and components of milk from Holstein $\times$ Zebu cows on Tanzania grass pastures using a fixed-rest period or $95 \%$ light interception. The treatments consisted of evaluations of two Tanzania-grass pasture-management strategies: LI95 - when the pasture reached 95\% light interception (LI), with 3 paddock-occupation days; and FR - the pasture was managed with a 30-days defoliation interval (DI) and 3 paddock-occupation days. Ten recently calved cows per treatment in year 1 and eight cows per treatment in year 2 were used, i.e. five cows per replicate in year 2 and four cows per replicate in year 2. Intake and digestibility of pasture nutrients, milk yield and milk composition were evaluated. The management strategies imposed on the Tanzania-grass pasture did not affect nutrient intake or digestibility. Milk yield and milk components were not affected by the management strategies, but milk yield per area unit was affected by the use of $95 \%$ light interception. The management strategy applying 95\% light interception implies greater efficiency in the use of area, which translates to a higher milk yield per unit area, and thus it can be recommended to increase milk yield per area.
\end{abstract}

KEYWORDS: Grass. Intake. Milk yield.

\section{INTRODUCTION}

Milk production systems on pasture have attracted increasing attention from technicians and producers as they allow for production with low costs, which promotes competitiveness and profitability in the industry. Thus, the sustainability of dairy farming depends on the adoption of a rational management strategy for cultivated pastures, whose conception of a milk production systems should be condition to judicious use of good-quality forage and production (BARCELLOS et al., 2008).

The literature reports that today it is possible to obtain from 12 to $14 \mathrm{~kg} / \mathrm{cow} / \mathrm{d}$ of milk on elephant grass pastures fertilized with 200 $\mathrm{kg} / \mathrm{ha} / \mathrm{yr}$ of nitrogen during the rainy season when managed under rotational stocking, with a 30-day defoliation interval (DANES et al., 2013). However, due to the reasonable cost of the pasture dry matter, this milk yield level should be maximized by the use of developed techniques for pasture management such as light interception and post-grazing residual heights, as shown in the studies (BRUNETTI et al.,
2016; CARVALHO et al., 2017; LEE; DONAGHY; ROCHE, 2008;).

The objective of these pasture-management techniques is to exploit the productive potential of forage plants. In order to exploit this potential, it is important to have favourable climatic conditions, vigorous regrowth after defoliation and efficient fertilization (SANTOS et al., 2012; FREITAS et al., 2012), and it is indispensable to understand how the forage plant grows and how the forage accumulation process takes place, i.e. the balance between the processes of growth and senescence that occur in the forage sward (MONTAGNER et al., 2012; SOUZA et al., 2013), given that, when grazing, ruminants select green leaves, rejecting the stems and senescing material (LEMAIRE; CHAPMAN, 1996). Additionally, besides indicating the yield, knowledge of the growth characteristics of grasses indicates the pasture defoliation intensity, in the case of continuous stocking, and the grazing frequency, in the case of rotational stocking (ZANINI; SANTOS; SBRISSIA, 2012).

In view of the above, the objective of this study was to evaluate nutrient intake and digestibility, yield and components of the milk from 
Holstein $\times$ Zebu cows on a Tanzania grass using a fixed-rest period or according to $95 \%$ light interception.

\section{MATERIAL AND METHODS}

The experiment was conducted at Embrapa Dairy Cattle, on the José Henrique Brushi experimental field, located in the municipality of Coronel Pacheco/MG, Brazil (2132'38" south latitude, $43^{\circ} 15^{\prime} 10^{\prime \prime}$ west longitude, $451 \mathrm{~m}$ altitude). According to the Köppen classification, the climate of that region is a humid mesothermal Cwa type, with rainy and hot summers and dry winters between June and September. The experiment took place between January and May 2009 (year 1) and 2011 (year 2). Meteorological data referring to the experimental period were also collected (Figures 1a and $b$ ).
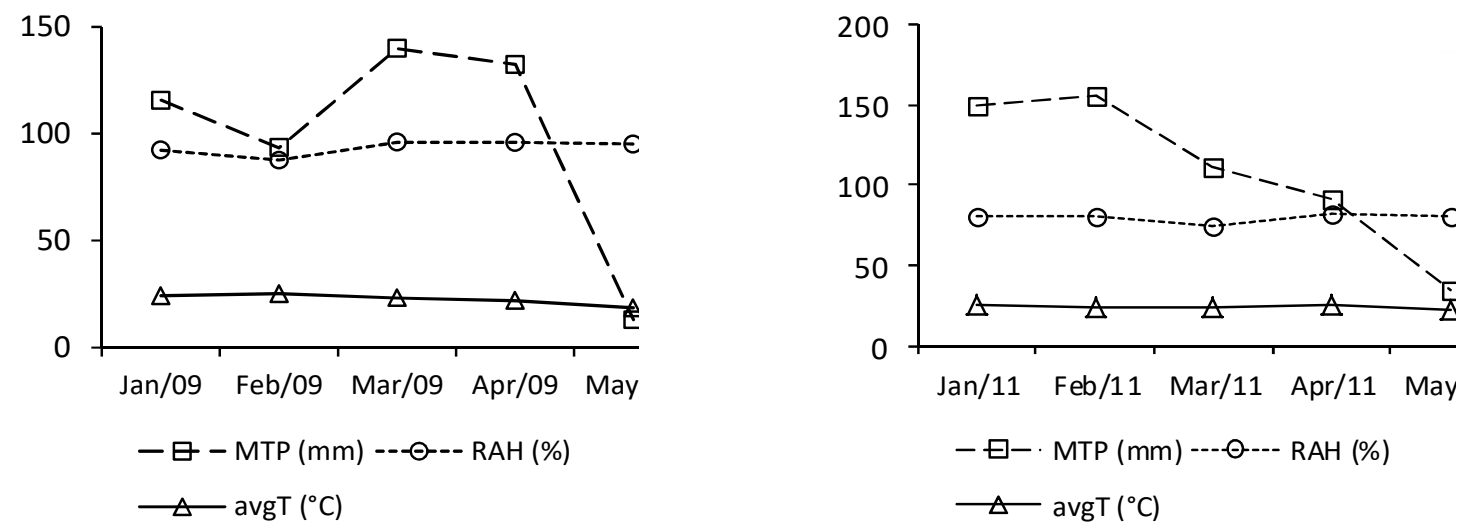

Figure 1. Monthly total precipitation (MTP), relative air humidity (RAH) and average monthly temperature (avgT) during the experimental period in year 1.

Note: The months of February, March, April and May represent cycles 1,2,3 and 4, respectively (a) and during the experimental period in year 2. Note: The months of February and March represent cycles 1 and 2, respectively (b).

Daily precipitation was graphed (Figure 2) to emphasize an anomalous period without rainfall, which occurred in the first months of year 2
(January and February) and affected the results of the experiment.

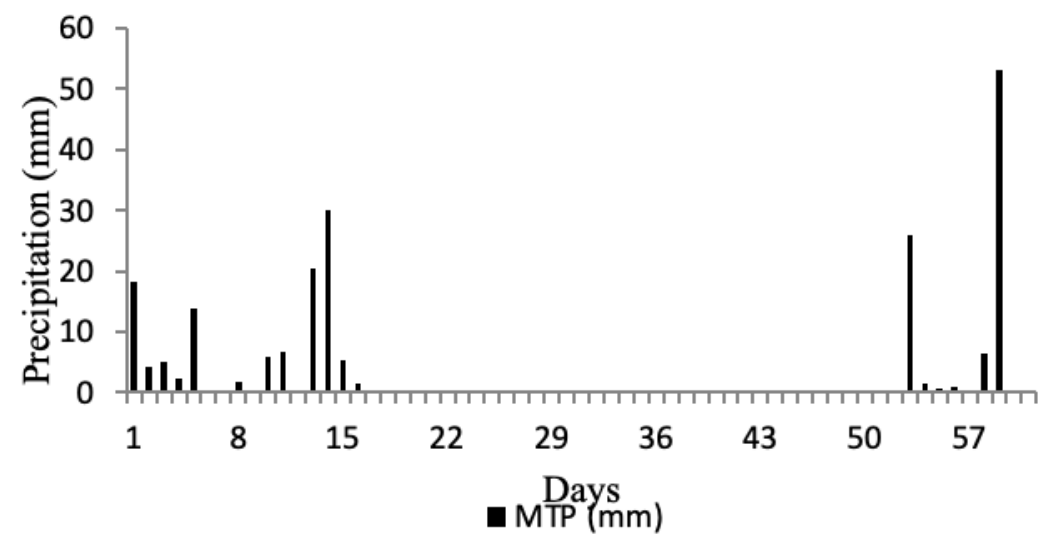

Figure 2. Daily total precipitation (DTP) in the period from January to February in year 2.

The experimental area consisted of 4 ha, divided into 44 paddocks measuring approximately $909 \mathrm{~m}^{2}$ each, with 22 paddocks per treatment. The treatments consisted of evaluations of two Tanzaniagrass pasture-management strategies: LI95 - animals entered the paddocks when the pasture reached $95 \%$ of light interception (LI), with 3 paddockoccupation days; and FR - the pasture was managed with a defoliation interval (DI) of 30 days and 3 paddock-occupation days. In treatment LI95, three extra paddocks of $909 \mathrm{~m}^{2}$ were prepared, aiming to adjust the LI in the different grazing cycles, since 
the DI could be shorter or longer than the adopted interval of 30 days, depending on the LI. However, according to the climatic conditions, the DI observed at LI95 was always shorter than or equal to the adopted interval of 30 days. Prior to the beginning of data collection, the pastures in both treatments were managed to establish post-grazing residual heights of $30 \mathrm{~cm}$. This management consisted of mechanical thinning performed with a backpack mower, which provided a plant age gradient in each paddock.

Paddocks were fertilized with $220 \mathrm{~kg} \mathrm{ha}^{-1} \mathrm{yr}^{-}$ ${ }^{1}$ of $\mathrm{N}$ and $\mathrm{K}_{2} \mathrm{O}$, and $55 \mathrm{~kg} \mathrm{ha}^{-1} \mathrm{yr}^{-1}$ of $\mathrm{P}_{2} \mathrm{O}_{5}$. Fertilization was performed by broadcasting whenever the animals were switched among paddocks over the grazing cycles, such that the
BAFFA et al.

nutrients were supplied in all paddocks when the pastures showed the same physiological age. Thus, $3.7 \mathrm{~kg}$ paddock $^{-1}$ cycle $^{-1}$ of $\mathrm{N}$ and $\mathrm{K}_{2} \mathrm{O}$, and $0.9 \mathrm{~kg}$ paddock $^{-1}$ cycle $^{-1}$ of $\mathrm{P}_{2} \mathrm{O}_{5}$ were supplied in the 20:05:20 commercial formula.

Ten recently calved cows $(1 / 2$ Holstein $\times 1 / 2$ Zebu blood) per treatment in year 1 , and eight cows per treatment in year 2 were used, i.e. five cows per replicate in year 1 and four cows per replicate in year 2. The cows were distributed per replicate in the treatments according to milk yield, number of lactations, live weight and breed group, such that the groups were homogeneous. During the experimental period, all cows were supplied with $2 \mathrm{~kg} / \mathrm{d}$ of concentrate, and minerals were supplied ad libitum (Table 1).

Table 1. Chemical composition of the concentrate and guaranteed levels (g per kg of product) of the mineral supplement supplied during the experimental period.

\begin{tabular}{|c|c|c|c|c|}
\hline Concentrate $\left(\mathrm{g} \mathrm{kg}^{-1}\right)$ & & & & \\
\hline$\overline{\mathrm{DM}}$ & $\mathrm{CP}$ & $\mathrm{MM}$ & $\mathrm{NDF}$ & $\overline{E E}$ \\
\hline 908.8 & 236.9 & 86.0 & 115.1 & 29.4 \\
\hline \multicolumn{5}{|c|}{ Mineral supplement ready for use - Dairy cattle } \\
\hline Calcium & & $193 \mathrm{~g}$ & & \\
\hline Cobalt & & $90 \mathrm{mg}$ & & \\
\hline Copper & & $1,500 \mathrm{mg}$ & & \\
\hline Sulfur & & $25 \mathrm{~g}$ & & \\
\hline Fluorine (maximum) & & $812.6 \mathrm{mg}$ & & \\
\hline Phosphorus & & $80 \mathrm{~g}$ & & \\
\hline Iodine & & $90 \mathrm{mg}$ & & \\
\hline Magnesium & & $20 \mathrm{~g}$ & & \\
\hline Manganese & & $3,000 \mathrm{mg}$ & & \\
\hline Selenium & & $25 \mathrm{mg}$ & & \\
\hline Sodium & & $120 \mathrm{~g}$ & & \\
\hline Zinc & & $5,000 \mathrm{mg}$ & & \\
\hline
\end{tabular}

DM - dry matter; CP - crude protein; MM - mineral matter; NDF - neutral detergent fiber; EE - ether extract.

The light intercepted by the sward was monitored pre-grazing every 7 days, and when the LI was close to the $95 \%$ target, the monitoring frequency was every 2 days. A variation of $\pm 2 \%$ in the LI was considered as criterion for animals to enter the paddocks, due to the low variation observed in the forage mass. For the assessments of LI, a sward analyser (AccuPAR Linear PAR/LAI ceptometer, Model PAR-80 (Decagon Devices)) was used, with readings made at ten points of the paddock. Three readings were taken at each point above the forage sward, and another three at soil level at representative points (taking topsoil into account) of the paddock in each replicate and in each grazing cycle.

In year 1 , the diet was sampled by using the extrusa, and to obtain representative samples of the diet, two oesophagus-fistulated animals were used. On the sampling days, the fistulated animals were gathered into the barn and feed-deprived for $12 \mathrm{~h}$; next, they were taken to the paddocks to graze for approximately $30 \mathrm{~min}$ to sample the material. Samples were conditioned in plastic bags and stored in a freezer at $-15{ }^{\circ} \mathrm{C}$ until the end of the collection period.

Extrusa samples were collected in all grazing cycles, and, after thawing, they were predried in a forced-ventilation oven at $\pm 55^{\circ} \mathrm{C}$ for $72 \mathrm{~h}$, ground in a 1-mm-sieve knife mill and stored in glass flasks at room temperature for laboratory analysis.

In year 2, however, the hand-plucking (grazing simulation) method was employed, and samples of the material originating from the 
regrowth of the pasture at the height of the forage sward above the residual were collected. Three collections were made per cycle in paddocks chosen at random. These samples were separated into leaves and stems and pre-dried in a forcedventilation oven at $\pm 55^{\circ} \mathrm{C}$ for $72 \mathrm{~h}$, then ground in a 1-mm-sieve knife mill and stored in glass flasks at room temperature for laboratory analysis.

All samples (originated from extrusa (year 1) and by hand-plucking (year 2)) were analysed for dry matter (DM, method 967.03 - AOAC, 1990), mineral matter (MM, method 942.05 - AOAC, 1990), ether extract (EE, method 920.29 - AOAC, 1990) and crude protein (CP, method 981.10 AOAC, 1990), and neutral detergent fiber (VAN SOEST; ROBERTSON, LEWIS, 1991). Non-fiber carbohydrates (NFC) and fiber carbohydrates (fiber) were determined according to Sniffen et al. (1992).

To estimate intake and digestibility, all cows were used -20 in year 1 and 16 in year 2 . Faecal production and intake were estimated by using the external marker chromic oxide $\left(\mathrm{Cr}_{2} \mathrm{O}_{3}\right)$. For each animal, $5 \mathrm{~g}$ of $\mathrm{Cr}_{2} \mathrm{O}_{3}$ were administered orally in paper cartridges twice daily, in 12-h intervals, for 12 days. Beginning 7 days after application, the necessary period for $\mathrm{Cr}_{2} \mathrm{O}_{3}$ to stabilize in the digesta, samples of faeces were collected manually from the rectum at the times of administration of $\mathrm{Cr}_{2} \mathrm{O}_{3}$ until the 12th day. At the end of the collection period, composite samples were made per animal for the 6-day collection period. Composite samples were dried in ovens at $\pm 55{ }^{\circ} \mathrm{C}$ for $72 \mathrm{~h}$ and processed to determine the chromium content by atomic absorption spectrometry after nitric-perchloric digestion.

Fecal production, intake and digestibility of DM were estimated by the equations below:

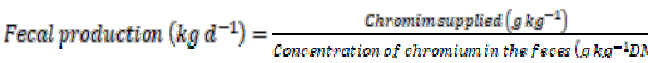

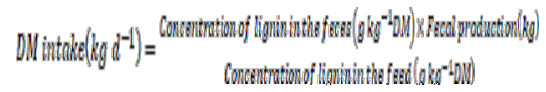

DV digestiblity $(\%)=1-\frac{\text { Fesclproduction }(\mathrm{kg} D \mathrm{DW})}{\text { LW intake }(\mathrm{kq} D \mathrm{DW})} \times 100$

The concentrations of lignin in the feces and in the feed were determined with the use of $\mathrm{H}_{2} \mathrm{SO}_{4}$, according to AOAC (1990).

The intakes of fiber and CP were calculated from the contents of ${ }_{\mathrm{a}} \mathrm{NDF}_{\mathrm{om}}$ and $\mathrm{CP}$ from the forage and the concentrate, as represented in the following equation:
Fiber intake $\left(k g d^{-1}\right)=\frac{F I\left(k g d^{-1}\right) \times Y \text { forago }(10)+C c\left(k g d^{-1}\right) \times Y \text { cona }(76)}{100}$

Where $F I=$ Forage intake; $C I=$ concentrate intake; $Y={ }_{a} N D F_{\text {om }}$ or $C P$.

The fiber digestibility was calculated by using equation 5 but replacing fecal production by fecal mass production of ${ }_{\mathrm{a}} \mathrm{NDF}_{\mathrm{om}}$ in the numerator and $\mathrm{DM}$ intake by ${ }_{\mathrm{a}} \mathrm{NDF}_{\mathrm{om}}$ intake in the denominator.

Thus, to calculate the estimated daily DM and fiber intakes, the following equation were used:

$D M$ intake $(\mathrm{kg})=\frac{[\text { Daily fesal production }(\mathrm{kg}) \times 100]}{\text { DM indigestibility }}$

in which:

Indigestibility $=100-$ Digestibility

The cows were milked twice daily, at 06.00 and 15.00. Milk samples were analyzed at every 14 days to determine the protein, fat and total solids (TS).

Milk yield per area (MYA) (kg milk/ha) was calculated in every cycle of years 1 and 2 , due to the variation in the area utilized in the treatments according to the management adopted. For instance, in complete 30 -day cycles, $100 \%$ of the area was utilized, which resulted in no difference between cow milk yield during the cycle (CMY) and MYA, because the area utilized in a 30-day cycle, in this study, was approximately 1 ha, but in 27 days, only $90 \%$ of the area was used, resulting in a higher milk yield, taking the utilized area into consideration $(\mathrm{MYA}=\mathrm{CMY} / 0.9)$. In a 24-day cycle, $80 \%$ of the area was utilized (MYA $=\mathrm{CMY} / 0.8)$, and so forth.

The net energy of the milk was estimated according to the NRC (2001), by the equation below:

$\operatorname{NE}\left(\mathrm{MJg}^{-1}\right)=4.1840 \times(0.0929 \times \% \mathrm{~F}+0.0547 \times \% \mathrm{CP}+0.0395 \times$ Lac

in which:

$N E=$ milk net energy; $F=$ milk fat; $C P=$ milk protein; and Lac $=$ milk lactose

The animals were weighed, and their body condition was evaluated at calving and then at every 14 days (Table 2 ). 
Table 2. Average live weight $(\mathrm{kg})$ of the cows during the experimental period.

\begin{tabular}{|c|c|c|c|c|c|c|}
\hline & \multicolumn{4}{|c|}{ Year 1} & \multicolumn{2}{|c|}{ Year 2} \\
\hline & \multicolumn{4}{|c|}{ Cycles } & \multicolumn{2}{|c|}{ Cycles } \\
\hline & 1 & 2 & 3 & 4 & 1 & 2 \\
\hline LI95 & 468 & 459 & 452 & 460 & 527 & 515 \\
\hline FR & 479 & 473 & 474 & 466 & 541 & 535 \\
\hline
\end{tabular}

LI95 - 95\% light interception; FR - fixed-rest period.

For the analyses of data of individual milk yield, milk chemical composition (fat, protein, lactose and total solids), intakes of DM, fiber and $\mathrm{CP}$, and, lastly, the digestibility of the DM and fiber, another model similar to the first one was used, but including the random effect of animal (cow) as can be seen below:

$Y_{i j k m}=\mu k+\alpha_{i}+r_{j(i)}+v_{m(i j)}+\tau_{k}+\beta_{I(k)}+\alpha \tau_{i k}+\alpha \beta_{i l k k)}+e_{i j k l m}$ in which $Y_{i j k \text { sm }}$ corresponds to the observation performed in the $j$-th replicate, in which the $i$-th treatment was applied during the $k$-th year and $l(k)$ th cycle in an $m$ (ij)-th animal; $\mu$ represents the overall mean; $\alpha_{i}$ corresponds to the effect of the $i$-th treatment $(i=1,2) ; r_{j(i)}$ represents the effect of the $j$-th replicate of area within the $i$-th treatment; $\tau_{k}$ represents the effect of the $k$-th year $(k=1,2) ; \beta_{l(k)}$ represents the effect of the $l$-th cycle within the $k$-th year; $\alpha \tau_{i k}$ is the interaction between the $i$-th treatment and the $k$-th year; $\alpha \beta_{i l(k)}$ is the interaction between the $i$-th treatment and the $l$-th cycle within the $k$-th year; $v_{m(i j)}$ represents the effect of the $m(i j)$-th animal; and $e_{i j k l}$ corresponds to the random error, normal assumption, independently and identically distributed, with zero mean and $\sigma^{2}$ variance.

The parameters were estimated using the MIXED procedure of SAS (Statistical Analysis System, version 9) software, in which the best structure among the studied variance and covariance was chosen based on the calculation of Akaike's information criterion (AlCcr; AKAIKE, 1974) and based on the probability of likelihood and on the evidence ratio of the derivatives. Likelihood values were compared based on calculations and choice criteria suggested by Vieira et al. (2012). The tested variance and co-variance structures, were: variance components, heterogeneous-variance components, compound symmetry, first-order autoregressive correlations, and Toeplitz structure (LITTELL et al., 2006).

The individual probability was calculated for each structure and in the cases of equivalence, the structure that showed the lowest value for
Akaike's information criterion $\left(\mathrm{AICc}_{\mathrm{r}}\right)$ was prioritized.

\section{RESULTS AND DISCUSSION}

For the variables crude protein intake, dry matter digestibility, fiber digestibility, individual milk yield, and milk composition the variancecovariance structures was heterogeneous-variance components. For Forage dry matter intake, fiber intake, and milk yield per hectare was first-order autoregressive.

The treatments applied and duration of the cycles between grazing sessions varied in treatment LI95. In year 1 (2009), cycles 1, 2, 3 and 4 lasted $24,24,27$ and 30 days, respectively. In year 2 (2011), cycles 1 and 2 lasted 27 and 30 days, respectively.

Regarding the forage dry-matter content, there was no effect of treatment $(\mathrm{P}=0.087)$, treatment $\times$ year interaction $(\mathrm{P}=0.490)$, cycle within year $(\mathrm{P}=0.447)$, or the treatment $\times$ cyclewithin-year interaction $(\mathrm{P}=0.928)$. A significant effect was only observed between years $(\mathrm{P}<0.001)$, in which years 1 and 2 showed values of $148.9 \pm$ 11.7 and $196.1 \pm 14.4 \mathrm{~g} \mathrm{~kg}^{-1} \mathrm{DM}$, respectively. There was no effect of treatment $(\mathrm{P}=0.135)$, treatment $\times$ year interaction $(\mathrm{P}=0.113)$, cycle within year $(\mathrm{P}=0.085)$, or the treatment $\times$ cyclewithin year interaction $(\mathrm{P}=0.903)$ on dry matter intake (DMI). However, there was a significant effect of the year $(\mathrm{P}<0.001)$, with values of $21.9 \pm$ 1.4 and $28.0 \pm 1.9 \mathrm{~g} \mathrm{DM} \mathrm{kg}^{-1} \mathrm{LW}$ in years 1 and 2 , respectively. A very important fact is that the lower stocking rate present in year 2 might have promoted a greater production of forage mass, thereby providing better selection of the pasture by the animals and, consequently, higher DMI.

The DMI is correlated with the digestibility of dry matter (DMD), because as DMD is increased, the DMI will also increase until the energy requirement is met. Cabral et al. (2011) stated that the rate of feed passage through the rumenreticulum is proportional to the increase in digestibility up to a maximum point. Thus, as DMD is reduced, the retention time of the digesta will be 
longer, causing a limitation in intake due to the rumen-fill effect. However, although the evaluation of DMI showed a significant difference between the years, no difference was found in relation to DMD $(\mathrm{P}=0.541)$; treatment LI95 displayed 505.7 \pm 31.2 $\mathrm{g} \mathrm{kg}^{-1} \mathrm{DM}$, and the FR treatment presented $492.4 \pm$ $31.2 \mathrm{~g} \mathrm{~kg}^{-1}$ DM. There was no effect of year $(\mathrm{P}=$ 0.749), treatment $\times$ year interaction $(\mathrm{P}=0.580)$, cycle within year $(\mathrm{P}=0.852)$ or treatment $\times$ cyclewithin-year interaction $(\mathrm{P}=0.260)$.

According to the chemical composition of the grass, the DM content was low in year 1. This may have resulted from the samples originating from the extrusa, because, according to some authors (FUKUMOTO et al., 2010; POMPEU et al., 2008; PORTO et al., 2009;), addition of saliva to the sample may influence the moisture content of the material. The difference between years, in regard to the DM content, can be explained by the different sampling methods utilized, which, in the case of year 2, was hand-plucking (grazing simulation), unlike year 1, when samples originated from the extrusa.

For mineral matter a significant effect was observed only between years $(\mathrm{P}<0.002)$, with $110.5 \pm 25.4$ and $116.5 \pm 13.3 \mathrm{~g} \mathrm{~kg}^{-1} \mathrm{DM}$ in years 1 and 2 , respectively. In this case, the difference could be explained by salivary contamination but by handplucking in year 2 or simply by sampling error, given that nothing else would justify the same grass, under the same conditions required by the experiment, showing contrasting differences. However, the crude fat content $(24.1 \pm 4.1$ and $5.8 \pm$ $2.8 \mathrm{~g} \mathrm{~kg}^{-1} \mathrm{DM}$ in years 1 and 2 , respectively) can be explained by differences in the sampling methods employed, i.e. the use of extrusa, in year 1 and hand-plucking in year 2 . The changes in inorganic components of oesophageal samples can be partially explained by salivary contamination (HOEHNE; CLANTON; STREETER, 1967). Crude fat represents the most energetic fraction of feeds; however, because grasses in general show lower contents than legumes (NRC, 2001), this component is not very relevant, although its evaluation is necessary for the knowledge of its content so as to estimate other fractions, e.g. total carbohydrates.

For crude protein (CP) intake, there were no effects of treatment $(\mathrm{P}=0.089)$ or the treatment $\times$ year interaction $(P=0.596)$. There were effects of year $(\mathrm{P}<0.001)$ and cycle within year $(\mathrm{P}<0.001)$, which were $2.1 \pm 0.1$ and $2.7 \pm 0.3 \mathrm{~g} \mathrm{DM} \mathrm{kg}^{-1}$ of LW for years 1 and 2, respectively, and there was a treatment $\times$ cycle-within-year interaction effect $(\mathrm{P}=$ 0.035) (Table 3).

Table 3. Crude protein content $\left(\mathrm{g} \mathrm{kg}^{-1} \mathrm{DM}\right)$ of Tanzania grass and protein intake $\left(\mathrm{g} \mathrm{DM} \mathrm{g} \mathrm{LW}^{-1}\right)$ of the cows.

\begin{tabular}{|c|c|c|c|c|c|c|}
\hline & \multicolumn{4}{|c|}{ Year 1} & \multicolumn{2}{|c|}{ Year 2} \\
\hline & \multicolumn{4}{|c|}{ Cycles } & \multicolumn{2}{|c|}{ Year } \\
\hline & 1 & 2 & 3 & 4 & 1 & 2 \\
\hline \multicolumn{7}{|c|}{ Crude protein content $\left(\mathrm{g} \mathrm{kg}^{-1} \mathrm{DM}\right)$} \\
\hline LI95 & $117.6 \mathrm{a} \pm 2.5$ & $97.5 \mathrm{c} \pm 2.3$ & $105.2 \mathrm{~b} \pm 2.4$ & $100.4 \mathrm{bc} \pm 2.4$ & $103.7 \pm 10.1$ & $81.1 \pm 9.0$ \\
\hline FR & $111.2 \mathrm{a} \pm 2.5$ & $101.1 \mathrm{~b} \pm 2.4$ & $99.7 \mathrm{~b} \pm 2.4$ & $89.6 \mathrm{c} \pm 2.2$ & $82.9 \pm 9.1$ & $92.6 \pm 9.6$ \\
\hline P-value & 0.061 & 0.461 & 0.018 & 0.036 & 0.057 & 0.47 \\
\hline \multicolumn{7}{|c|}{ Crude protein intake $\left(\mathrm{g} \mathrm{DM} \mathrm{g} \mathrm{LW}^{-1}\right)$} \\
\hline LI95 & $2.4 \mathrm{a} \pm 0.4$ & $2.2 \mathrm{a} \pm 0.2$ & $2.3 \mathrm{a} \pm 0.3$ & $2.0 \mathrm{a} \pm 0.2$ & $2.8 \pm 0.3$ & $2.8 \pm 0.3$ \\
\hline FR & $2.2 \mathrm{ab} \pm 0.4$ & $2.3 \mathrm{a} \pm 0.2$ & $2.0 \mathrm{ab} \pm 0.2$ & $1.6 \mathrm{~b} \pm 0.2$ & $2.5 \pm 0.3$ & $2.5 \pm 0.3$ \\
\hline P-value & 1.000 & 0.994 & 0.909 & 0.037 & 0.997 & 0.997 \\
\hline
\end{tabular}

Means followed by the same letter in the same row and in the same year do not differ statistically at $\alpha=0.05$.

LI95 - 95\% light interception; FR - fixed-rest period.

These differences were expected, insofar as the environmental variables associated with the flowering time have an effect on the physiology of the grass. Thus, as a rainy season is shifted to a dry season, the decrease in ambient temperature (Figures 1a and b) associated with flowering and the reduction of nutrient availability, which are normally found under water-stress conditions, may be responsible for the observed decline of the $\mathrm{CP}$ content. The CP levels for Tanzania grass observed by Porto et al. (2009) and Fukumoto et al. (2010) were similar to those found in the current study.

Regarding the crude protein content, year 2 was superior to year $1(\mathrm{P}<0.001)$, partially due to the greater proportion of leaves in year 2 (Table 3 ), given that a large portion of the protein ingested by the animal is concentrated in this part of the plant. The observed values (Table 3) can be considered normal, although they were $15.86 \%$ to $68 \%$ higher than the minimum limitation value, which, 
according to Van Soest (1994), is $70 \mathrm{~g} \mathrm{~kg}^{-1} \mathrm{CP}$ (in the DM) to ensure the fermentation of carbohydrate fibres in the rumen.

For NDF intake, there was no effect of treatment $(\mathrm{P}=0.052)$ or the treatment $\times$ cyclewithin-year interaction $(\mathrm{P}=0.853)$. This variable was affected by the year $(\mathrm{P}=0.009)$, with $16.3 \pm 1.5$ and $13.4 \pm 1.5 \mathrm{~g}$ of $\mathrm{DM} \mathrm{kg}{ }^{-1}$ of $\mathrm{LW}$ in years 1 . There were treatment $\times$ year interaction $(\mathrm{P}=0.040)$ and cycle within year $(\mathrm{P}=0.049)$ effects (Table 4$)$. In this study, ${ }_{a} \mathrm{NDF}_{\text {om }}$ was considered to represent the carbohydrate fibres present in the forage.

Table 4. Mean values of neutral detergent fiber intake $\left(\mathrm{g} \mathrm{DM} \mathrm{kg} \mathrm{LW}^{-1}\right)$ for cycle within year

\begin{tabular}{lcccccc}
\hline & Year 1 & \multicolumn{3}{c}{ Year 2 } \\
\hline Cycles & 1 & 2 & 3 & 4 & 1 & 2 \\
\hline Means & $15.0 \mathrm{ab} \pm 1.5$ & $16.3 \mathrm{a} \pm 1.5$ & $15.3 \mathrm{ab} \pm 1.5$ & $13.4 \mathrm{~b} \pm 1.5$ & $14.7 \pm 1.7$ & $14.9 \pm 1.7$ \\
\hline
\end{tabular}

Means followed by the same letter in the same row and in the same year do not differ statistically at $\alpha=0.05$.

Quantifying the levels of NDF is important because of its inverse relationship with the voluntary forage intake, due to the rumen-fill effect. The rumen fill is determined by the ruminal capacity, the type of roughage, its NDF content, the particle size, the fragility of the fibre, and the degradability of this NDF (MERTENS, 1992). The fibrous fraction is less dense and more slowly digested than the other feed fractions, which fosters its retention in the rumen compartment (VIEIRA; TEDESCHI; CANNAS, 2008). The fibre content in our study was not influenced by the cycles and years, so the NDF intake levels were not influenced (Table 4).

The observed NDF contents can be considered normal for tropical grasses, taking into account their physiological age at the moment of sampling, and they are also similar to those observed by Patês et al. (2008); Porto et al. (2009), but higher than those obtained by Fukumoto et al. (2010).

Regarding fibre digestibility, there was no effect of treatment $(\mathrm{P}=0.855)$, treatment $\times$ year interaction $(\mathrm{P}=0.119)$, cycle within year $(\mathrm{P}=$ $0.949)$, or the treatment $\times$ cycle-within-year interaction $(P=0.706)$. A significant effect was observed between the years $(\mathrm{P}<0.001)$, in which years 1 and 2 showed $627.6 \pm 9.7$ and $493.6 \pm 51.4$ $\mathrm{g} \mathrm{kg}^{-1} \mathrm{DM}$, respectively. There was no variation in fibre digestibility among the evaluated treatments and grazing cycles. The grazing pressure applied to the Tanzania grass modules was likely low, so these animals had a greater opportunity to select the composition of their diets, which promoted the choice of more palatable and nutritive parts (FERNANDES et al., 2014); this gave the diets of cows in both treatments a similar chemical composition.

Non-fibre carbohydrates (NFC) were not affected by treatment $(\mathrm{P}=0.265)$, treatment $\times$ year interaction $(\mathrm{P}=0.923)$, cycle within year $(\mathrm{P}=$
$0.195)$, or the treatment $\times$ cycle-within-year interaction $(P=0.238)$, and a significant effect was only observed between years $(\mathrm{P}=0.001)$, with values of $147.9 \pm 71.0$ and $237.4 \pm 79.3 \mathrm{~g} \mathrm{NFC} \mathrm{kg}^{-1}$ $\mathrm{DM}$, for years 1 and 2 , respectively.

The non-fibre carbohydrates were influenced only by the years, because they are located in the cell content (except for pectin, which is in the cell wall), and are found at greater amounts in the seeds, leaves and stalks and represent energy reserves used for reproduction, growth and survival during a period of stress (MERTENS, 1992). This fraction is also degraded faster than fibrous carbohydrates because it is composed of pectin, starch and sugars. Moreover, as their physiological maturation is advanced, their lignin and fibre contents increase, i.e. as the grass ages, the cell content is reduced.

Therefore, the increased intake of energy from carbohydrate sources elevates the percentage and production of protein in milk. It is estimated that around $85 \%$ of the increase in protein results from higher milk production, whereas only $15 \%$ of this response is related to an increase in the percentage of protein in milk. The intake of rapidly fermentable NFC supplies readily available energy for rumen microorganisms to synthesize microbial protein, i.e., the increased energetic density of the diet depends on the supply of higher amounts of concentrate, which increases propionic acid production in the rumen. There seems to be a positive relationship between the propionic acid produced in the rumen and the milk protein content. Lima et al. (2011) hypothesised that the production of microorganisms which have propionic acid as the main end-product of fermentation must have an amino-acid profile more suitable for milk protein synthesis. In the present study, despite the change in the lignin contents during the cycles of year 2, there was no reduction of the cell content, i.e. NFC. 
The individual milk yield was not affected by treatment $(\mathrm{P}=0.910)$, treatment $\times$ year interaction $(\mathrm{P}=0.398)$, or treatment $\times$ cycle-withinyear interaction $(\mathrm{P}=0.521)$. However, it was affected by the year $(\mathrm{P}<0.001)$ and cycle within year $(\mathrm{P}<0.001)$ (Table 5). Individual milk yield underwent a gradual reduction as the cycles progressed in year 1, probably due to the drop in the forage protein content in the last cycle (Table 5). Greater individual yields were observed in year 2, which is explained by the lower grazing pressure exerted and the greater forage mass in that year.

Table 5. Milk yield and components according to cycle within year.

\begin{tabular}{|c|c|c|c|c|c|c|}
\hline \multirow[b]{2}{*}{ Cycles } & \multicolumn{4}{|c|}{ Year 1} & \multicolumn{2}{|c|}{ Year 2} \\
\hline & 1 & 2 & 3 & 4 & 1 & 2 \\
\hline \multicolumn{7}{|c|}{ Milk yield (kg milk cow ${ }^{-1}$ ) } \\
\hline Means & $14.5 \mathrm{a} \pm 1.0$ & $13.2 \mathrm{~b} \pm 1.0$ & $11.7 \mathrm{c} \pm 1.0$ & $9.4 \mathrm{~d} \pm 1.0$ & $16.1 \pm 2.2$ & $14.9 \pm 2.2$ \\
\hline \multicolumn{7}{|c|}{ Protein content ( $\mathrm{g} \mathrm{kg}^{-1}$ milk) } \\
\hline Means & $29.8 b \pm 1.1$ & $29.5 \mathrm{~b} \pm 1.0$ & $29.2 \mathrm{~b} \pm 1.0$ & $32.2 \mathrm{a} \pm 1.1$ & $29.5 \mathrm{~b} \pm 2.1$ & $33.8 \mathrm{a} \pm 2.3$ \\
\hline \multicolumn{7}{|c|}{ Lactose content ( $\mathrm{g} \mathrm{kg}^{-1}$ milk$)$} \\
\hline Means & $53.8 \mathrm{ac} \pm 24.7$ & $43.6 \mathrm{a} \pm 1.2$ & $43.4 \mathrm{a} \pm 1.0$ & $40.5 b c \pm 1.3$ & $44.0 \pm 2.3$ & $43.6 \pm 2.0$ \\
\hline \multicolumn{7}{|c|}{ Milk net energy ( $\mathrm{MJ} \mathrm{kg}^{-1}$ milk) } \\
\hline Means & $9.286 a b \pm 6.2$ & $9.009 \mathrm{~b} \pm 2.9$ & $8.903 \mathrm{~b} \pm 2.6$ & $9.578 \mathrm{a} \pm 3.4$ & $9.437 \pm 7.5$ & $10.120 \pm 5.9$ \\
\hline
\end{tabular}

Means followed by the same letter in the same row and in the same year do not differ statistically at $\alpha=0.05$.

Energy and protein supplies may interact to affect milk yield and milk composition. The increase in metabolizable protein supply generally enhances DMI (and thus the energy supply), especially when protein requirements are not satisfied, even if the digestibility of the diet does not change (FAVERDIN; M'HAMED; VÉRITÉ, 2003). In addition, protein can alter the efficiency of use of absorbed nutrients, its partition toward mammary secretion or both (OLDHAN, 1984).

Regarding milk fat content (F), there was no effect of treatment $(\mathrm{P}=0.653)$. Treatment LI95 showed $43.1 \pm 6.1 \mathrm{~g} \mathrm{~F} \mathrm{~kg}^{-1}$ milk, and treatment FR, $41.0 \pm 6.0 \mathrm{~g} \mathrm{~F} \mathrm{~kg}^{-1}$ milk. There was no effect of the treatment $\times$ year interaction $(\mathrm{P}=0.864)$, cycle within year $(\mathrm{P}=0.273)$, or treatment $\times$ cycle within year interaction $(\mathrm{P}=0.599)$, but weak evidence of an effect between years was observed $(\mathrm{P}=0.073)$ for years 1 and 2, which had $38.7 \pm 2.5$ and $45.3 \pm$ $7.8 \mathrm{~g} \mathrm{~F} \mathrm{~kg}^{-1}$ milk, respectively. Feeding of readily fermentable carbohydrates depresses fibre digestion and $\mathrm{pH}$ in the rumen and thus decreases acetic and butyric acid production and increases propionic acid production. Increased propionic acid concentrations in the rumen lead to increased lactic acid and glucose production, which, in turn, stimulates insulin production, reducing free-fatty-acid release from adipose tissue. Thus, the main precursors of milk fat (acetic and butyric acids derived from rumen fermentation, long-chain fatty acids of dietary origin and acetic acid and long-chain fatty acids from endogenous sources) can be affected by diet through changes in rumen fermentation or addition of fats for direct absorption and inclusion into milk fat (NRC, 2001).

For solids non-fat or total solids (TS), there was no effect of treatment $(\mathrm{P}=0.744)$; treatment LI95 yielded $126.7 \pm 7.0 \mathrm{~g} \mathrm{TS} \mathrm{kg}^{-1}$ milk, whereas the FR treatment showed $125.2 \pm 6.8 \mathrm{~g} \mathrm{TS} \mathrm{kg}^{-1}$ milk. There were also no effects of treatment $\times$ year interaction $(\mathrm{P}=0.894)$, cycle within year $(\mathrm{P}=$ 0.202 ), or treatment $\times$ cycle-within-year interaction $(\mathrm{P}=0.230)$. A significant effect was observed between years $(\mathrm{P}=0.008)$, in which years 1 and 2 had $120.5 \pm 3.3$ and $131.6 \pm 8.3 \mathrm{~g} \mathrm{TS} \mathrm{kg}^{-1}$ milk, respectively.

No effect of treatment $(\mathrm{P}=0.874)$ or treatment $\times$ year interaction $(\mathrm{P}=0.478)$ was observed on the milk protein content, but there was weak evidence of an effect of treatment $\times$ cyclewithin-year interaction $(\mathrm{P}=0.070)$. A significant effect was observed between years $(\mathrm{P}=0.048)$ and cycle within years $(\mathrm{P}<0.001)$ (Table 5).

The highest milk protein content was found in cycle 4 (Table 5). This response must be associated with the crude protein levels of the grass, since alterations in protein intake have a discrete effect on milk composition (PORTO et al., 2009). Yet the opposite occurred, as a lower protein content of the grass was observed in this cycle (Table 3), with a consequent lower crude-protein intake by the animals (Table 3, only in FR). A similar process occurred in year 2, when there was a significant difference between the cycles, wherein 
cycle 2 recorded higher milk protein levels (Table 5 ), higher forage protein contents (Table 3 , only in LI95) and no differences in protein intake (Table 3 ). The protein contents, as well as the non-fat milk solids observed in the literature (FUKUMOTO et al., 2010; PORTO et al., 2009), corroborate the values reported in the present study.

The milk lactose content was not impacted by treatment $(\mathrm{P}=0.379)$, year $(\mathrm{P}=0.632)$, treatment $\times$ year interaction $(\mathrm{P}=0.266)$, or treatment $\times$ cyclewithin-year interaction $(\mathrm{P}=0.143)$. However, a significant effect was observed on this variable for cycle within year $(\mathrm{P}=0.001)$ (Table 5). The milk lactose contents were lower in cycle 4 as compared with the other grazing cycles, except the first (Table 5 ). This trend may be a consequence of the NFC content of the forage supplied to the animals in this cycle, which, despite not having resulted in a significant difference, might have provided lower levels of glucose - the only lactose precursor in the mammary glands - and, as a consequence, lower deposition of lactose in the milk.

No effects of treatment $(\mathrm{P}=0.785)$ or treatment $\times$ year interaction $(\mathrm{P}=0.869)$ were found on the net energy contained in the milk. Yet, a significant effect was observed between years $(\mathrm{P}=$ $0.013)$, cycle within year $(P<0.001)$, and for the treatment $\times$ cycle-within-year interaction $(\mathrm{P}=$ 0.003) (Table 6). The net energy contained in the milk determines how much energy was effectively deposited in it and is equivalent to the sum of the heat combustions of the milk fat, protein and lactose (NRC, 2001). Thus, the observed values are a result of the contents of these three variables, and thus cycle 4 had higher values than those found in the other grazing cycles (Table 6).

Table 6. Mean values of net energy $\left(\mathrm{MJ} \mathrm{kg}^{-1}\right.$ of milk) contained in the milk

\begin{tabular}{|c|c|c|c|c|c|c|}
\hline \multicolumn{5}{|c|}{ Year 1} & \multicolumn{2}{|c|}{ Year 2} \\
\hline & \multicolumn{4}{|c|}{ Cycles } & \multicolumn{2}{|c|}{ Cycles } \\
\hline & 1 & 2 & 3 & 4 & 1 & 2 \\
\hline LI95 & $9.510 \mathrm{ab} \pm 9.1$ & $8.829 \mathrm{~b} \pm 4.1$ & $9.041 \mathrm{ab} \pm 3.7$ & $9.508 \mathrm{a} \pm 4.7$ & $9.393 b \pm 10.5$ & $10.299 \mathrm{a} \pm 8.7$ \\
\hline FR & $9.063 \mathrm{ab} \pm 8.8$ & $9.190 \mathrm{a} \pm 4.0$ & $8.764 \mathrm{~b} \pm 3.8$ & $9.649 \mathrm{a} \pm 4.7$ & $9.484 \pm 10.5$ & $9.940 \pm 8.4$ \\
\hline P-value & 1.000 & 0.976 & 0.994 & 1.000 & 1.000 & 1.000 \\
\hline
\end{tabular}

Means followed by the same letter in the same row and in the same year do not differ statistically at $\alpha=0.05$.

LI95 - 95\% light interception; FR - fixed-rest period.

Regarding the milk yield per hectare, there was no effect of treatment $(\mathrm{P}=0.166)$, year $(\mathrm{P}=$ $0.631)$ or treatment $\times$ cycle-within-year interaction $(\mathrm{P}=0.075)$. A significant effect was observed for cycle within year $(\mathrm{P}<0.001)$ and for the treatment $\times$ year interaction $(\mathrm{P}=0.046)$. Treatment LI95 showed 2,067 $\pm 288 \mathrm{~kg}^{-1} \mathrm{~m} \mathrm{ha}^{-1}$ and treatment FR, $1,861 \pm 288 \mathrm{~kg}$ milk ha ${ }^{-1}$. The estimates for the confidence interval at $95 \%$, for years 1 and 2 were $1,987 \pm 212$ and $1,940 \pm 219 \mathrm{~kg} \mathrm{milk} / \mathrm{ha}$, respectively. The milk yield obtained in cycles 1,2 , 3 and 4 of year 1 were $2,451 \pm 226 ; 2,240 \pm 226$; $1,851 \pm 226$; and $1,406 \pm 226 \mathrm{~kg} \mathrm{ha}^{-1}$, respectively. The milk yield of cycles 1 and 2 of year 2 were $2,064 \pm 226$ and $1,817 \pm 226 \mathrm{~kg} \mathrm{ha}^{-1}$, respectively. In the treatment $\times$ year interaction, treatments LI95 and FR, in year 1, produced 2,196 \pm 300 and 1,777 $\pm 300 \mathrm{~kg} \mathrm{milk} \mathrm{ha}{ }^{-1}$, respectively, and differed statistically $(\mathrm{P}=0.049)$. Treatments LI95 and FR, in year 2, however, provided $1,937 \pm 310$ and $1,944 \pm$ $310 \mathrm{~kg}$ milk ha ${ }^{-1}$, respectively, and did not differ statistically from one another $(\mathrm{P}=1.000)$. This yield was probably due to the smaller area utilized, because when the individual milk yields of the treatments were evaluated, no statistical difference was detected.

In both years, similar behaviours were observed among treatments, with a decreasing productivity over the cycles due to the progression of the lactation periods of the cows and the lower quantity and quality of available forage in drier periods.

\section{CONCLUSIONS}

Management with the use of $95 \%$ light interception increases the protein content of the grass ingested by cows. In year 1 , this management implies greater efficiency in the use of the area; in other words, higher milk yield per area unit.

The use of $95 \%$ light interception is recommended as a management strategy to increase the milk yield per area. 
RESUMO: O objetivo deste estudo foi avaliar a ingestão e digestibilidade dos nutrientes, produção e os componentes do leite de vacas Holandesas $\times$ Zebu em pastagens de capim-Tanzânia em repouso fixo ou $95 \%$ de interceptação de luz. Os tratamentos consistiram de avaliações de duas estratégias de manejo de pastagem de capim Tanzânia: LI95 - quando a pastagem atingiu 95\% de interceptação luminosa (LI), com três dias de ocupação do piquete; e TF - a pastagem foi manejada com intervalo de 30 dias de desfolha (ID) e três dias de ocupação do piquete. Dez vacas recém-paridas foram utilizadas por tratamento no ano 1 e oito vacas por tratamento no ano 2. Consumo e digestibilidade dos nutrientes do pasto, produção de leite e leite composição foram avaliados. As estratégias de manejo aplicadas na pastagem de capim-tanzânia não afetaram o consumo ou a digestibilidade dos nutrientes. A produção de leite e os componentes do leite não foram afetados pelas estratégias de manejo, mas a produção de leite por unidade de área foi afetada pelo uso de $95 \%$ de interceptação de luz. O manejo adotando $95 \%$ de interceptação de luz implica maior eficiência no uso da área, o que significa maior rendimento de leite por unidade de área, e assim pode ser recomendado aumentar a produção de leite por área.

PALAVRAS-CHAVE: Gramínea. Ingestão. Produção de leite.

\section{REFERENCES}

AKAIKE, H. A new look at the statistical model identification. IEEE Transactions on Automatic Control, Hoes Lane, v.19, n. 6, p.716-723, 1974. https://doi.org/10.1109/TAC.1974.1100705

Association of Official Analytical Chemistry (AOAC). Official Methods of Analysis. 15th ed. Arlington: AOAC International, 1990.

BARCELLOS, A. O.; RAMOS, A. K. B.; VILELA, L.; JUNIOR, G. B. M. Sustentabilidade da produção animal baseada em pastagens consorciadas e no emprego de leguminosas exclusivas, na forma de banco de proteína, nos trópicos brasileiros. Revista Brasileira de Zootecnia, Viçosa, v. 37, p. 51-67, 2008. https://doi.org/10.1590/S1516-35982008001300008

BRUNETTI, H. B.; CARVALHO, L. R.; CHIAVEGATO, M. B.; SILVA, C. S. Sward structure, light interception and herbage accumulation in forage peanut cv. Belmonte subjected to strategies of intermittent grazing management. Acta Scientiarum. Animal Sciences, Maringá, v. 38, n. 4, p. 395-404, 2016. https://doi.org/10.4025/actascianimsci.v38i4.32207

CABRAL, L. S.; VALADARES FILHO, S. C.; DETMANN, E.; ZERVOUDAKIS, J. T.; GALATI, R. L.; SOUSA, D. P.; SOUZA, A. L. Simulation and validation of the ruminal digestion of carbohydrates in cattle from kinetic parameters obtained by in vitro gas production technique. Revista Brasileira de Zootecnia, Viçosa, v.40, n.9, p.1984-1990, 2011. https://doi.org/10.1590/S1516-35982011000900020

CARVAlHO, A. L. S.; MARTUCELlO, J. A.; ALMEIDA, O. G; BRAZ, T. G. S.; CUNHA, D. N. F. V.; JANK, L. Production and quality of Mombaça grass forage under different residual heights, Acta Scientiarum. Animal Sciences, Maringá, v. 39, n. 2, p. 143-148, 2017. https://doi.org/10.4025/actascianimsci.v39i2.34599

DANES, M. A.; CHAGAS, L. J.; PEDROSO, A. M.; SANTOS, F.A. Effect of protein supplementation on milk production and metabolism of dairy cows grazing tropical grass. Journal of Dairy Science, Park Ave, v. 96, n. 1, p. 407-419, 2013. https://doi.org/10.3168/jds.2012-5607

FAVERDIN, P.; M'HAMED, D.; VÉRITÉ, R. Effects of metabolizable protein on intake and milk production of dairy cows independent of effects on ruminal digestion. Animal Science, London, v. 76, n. 1, p. 137-146, 2003. https://doi.org/10.1017/S135772980005339X

FERNANDES, A. M.; DERESZ, F.; HENRIQUE, S. H.; LOPES, F.C.F.; GLORIA, S.L. Nutritive value of Tanzania grass for dairy cows under rotational grazing. Revista Brasileira de Zootecnia, Viçosa, v. 43, n. 8, p. 410-418, 2014. https://doi.org/10.1590/S1516-35982014000800003 
FREITAS, F. P.; FONSECA, D. M.; BRAZ, T.G.S.; MARTUSCELLO, J. A., SANTOS, M. E. R. Forage yield and nutritive value of Tanzania grass under nitrogen supplies and plant densities. Revista Brasileira de Zootecnia, Viçosa, v.41, n.4, p.864-872, 2012. https://doi.org/10.1590/S1516-35982012000400006

FUKUMOTO, N. M.; DAMASCENO, C. J.; DERESZ, F.; MARTINS, C. M.; COSER, A.C.; SANTOS, G. T. Produção e composição do leite, consumo de matéria seca e taxa de lotação em pastagens de gramíneas tropicais manejadas sob lotação rotacionada. Revista Brasileira de Zootecnia, Viçosa, v.39, n. 7, p.1548-1557, 2010.

HOEHNE, O. E.; CLANTON, D. C.; STREETER, C. L. Chemical Changes in Esophageal Fistula Samples Caused by Salivary Contamination and Sample Preparation. Journal of Animal Science, Evans RD, v. 26, n. 3, p. 628-631, 1967. https://doi.org/10.2527/jas1967.263628x

LEE, J. M.; DONAGHY, D. J.; ROCHE, J. R. Effect of post-grazing residual pasture height on milk production. Journal of Dairy Science, Park Ave, v. 91, n. 11, p. 4307-4311, 2008.

https://doi.org/10.3168/jds.2008-1188

LIMA, L.S.; OLIVEIRA, R.L.; BAGALDO, A. R.; GARCEZ NETO, A.F.; RIBEIRO, C.V.D.M.; LANNA, D.P.D. Composition and fatty acid profile of milk from cows on pasture subjected to licuri oil supplement. Revista Brasileira de Zootecnia, Viçosa, v.40, n.12, p.2858-2865, 2011. https://doi.org/10.1590/S151635982011001200033

LEMAIRE, G.; CHAPMAN, D. Tissue fluxes in grazing plants communities. Wallingford: CAB International, 1996.

LITTELL, R. C.; MILLIKEN, G. A.; STROUP, W. W.; WOLFINGER, R. D.; SCHABENBERGER, O. SAS® for Mixed Models, North Caroline: SAS Institute Inc., Cary, 2006.

MERTENS, D. R Análise da fibra e sua utilização na avaliação de alimentos e formulação de rações. Simpósio Internacional de Ruminantes. Lavras: UFLA, 1992.

MONTAGNER, D. B.; NASCIMENTO JÚNIOR, D.; SILVEIRA, M. C. T.; VILELA, H. H.; SOUSA, B. M. L.; EUCLIDES, V. P. B.; SILVA, S.C.; CARLOTO, M. N. Morphogenesis in guinea grass pastures under rotational grazing strategies. Revista Brasileira de Zootecnia, Viçosa, v. 41, n. 4, p.883-888, 2012. https://doi.org/10.1590/S1516-35982012000400008

National Research Council (NRC). Nutrient requirements of dairy cattle. 7. ed. Washington: National, Academy Press, 2001.

OLDHAN, J. D. Protein-energy interrelationships in dairy-cows. Journal of Dairy Science, Park Ave, v. 67, n.5, p. 1090-1114, 1984. https://doi.org/10.3168/jds.S0022-0302(84)81410-1

PATÊS, N. M. S.; PIRES, A. J. V.; CARVALHO, G. G. P.; OLIVEIRA, A. C.; FONCÊCA, M. P.; VELOSO, C. M. Produção e valor nutritivo do capim-tanzânia fertilizado com nitrogênio e fósforo. Revista Brasileira de Zootecnia, Viçosa, v. 37, n. 11, p.1934-1939, 2008. https://doi.org/10.1590/S1516-35982008001100005

POMPEU, R. C. F. F.; CÂNDIDO, M. J. D.; NEIVA, J. N. M.; ROGÉRIO, M. C. P.; FACÓ, O. Componentes da biomassa pré-pastejo e pós-pastejo de capim-tanzânia sob lotação rotativa com quatro níveis de suplementação concentrada. Revista Brasileira de Zootecnia, Viçosa, v. 37, n. 3, p.383-393, 2008. https://doi.org/10.1590/S1516-35982008000300002

PORTO, P. P.; DERESZ, F.; SANTOS, G. T.; LOPES, F. C. F.; CECATO, U.; CÓSER, A. C. Produção e composição química do leite, consumo e digestibilidade de forragens tropicais manejadas em sistema de lotação intermitente. Revista Brasileira de Zootecnia, Viçosa, v. 38, n. 8, p. 1422-1431, 2009. https://doi.org/10.1590/S1516-35982009000800005 
SANTOS, M. E. R.; FONSECA, D. M.; GOMES, V. M.; BRAZ, T. G. S.; SILVA, S. P.; ALBINO, R. L.; SANTOS, A. L.; SILVA, G. P. Grazing patterns on signal grass pasture according to location of cattle feces. Revista Brasileira de Zootecnia, Viçosa, v. 41, n. 4, p.898-904, 2012. https://doi.org/10.1590/S151635982012000400010

SNIFFEN, C. J.; O’CONNOR, J. D.; VAN SOEST, P. J.; FOX, D. G.; RUSSELL, J. B. A Net Carbohydrate and Protein System for Evaluating Cattle Diets. II. Carbohydrate and Protein Availability. Journal of Animal Science, Evans RD, v. 70, n. 11, p.3562-3577, 1992. https://doi.org/10.2527/1992.70113562x

SOUZA, B. M. L.; NASCIMENTO JÚNIOR, D.; MONTEIRO, H. C. F.; SILVA, S. C.; VILELA, H. H.; SILVEIRA, M. C. T.; RODRIGUES, C. S.; SBRISSIA, A. F. Dynamics of forage accumulation in Elephant grass subjected to rotational grazing intensities. Revista Brasileira de Zootecnia, Viçosa, v. 42, n. 9, p.629638, 2013. https://doi.org/10.1590/S1516-35982013000900004

VAN SOEST, P. J.; ROBERTSON, J. B.; LEWIS, B. A. Methods for dietary fiber, neutral detergent fiber, and nonstarch polysaccharides in relation to animal nutrition. Journal of Dairy Science, Park Ave, v. 74, n. 10, p.3583-3597, 1991. https://doi.org/10.3168/jds.S0022-0302(91)78551-2

VAN SOEST, P. J. Nutritional ecology of the ruminant. 2. Ed. Ithaca: Cornell University. 1994.

VIEIRA, R. A. M.; TEDESCHI, L. O.; CANNAS, A. A generalized compartmental model to estimate the fiber mass in the ruminoreticulum: 2. Integrating digestion and passage. Journal of Theoretical Biology, London, v. 255, n. 4, p.345-356, 2008. https://doi.org/10.1016/j.jtbi.2008.08.014

VIEIRA, R. A. M., CAMPOS, P. R. S.; SILVA, J. F. C., TEDESCHI, L. O.; TAMY, P. W. Heterogeneity of the digestible insoluble fiber of selected forages in situ. Animal Feed Science and Technology, Radarweg, v.171, n. 2, p.154-166, 2012. https://doi.org/10.1016/j.anifeedsci.2011.11.001

ZANINI, G. D.; SANTOS, G.T.; SBRISSIA, A. F. Frequencies and intensities of defoliation in Aruana guinea grass swards: morphogenetic and structural characteristics. Revista Brasileira de Zootecnia, Viçosa, v.41, n.8, p.1848-1857, 2012. https://doi.org/10.1590/S1516-35982012000800007 